\title{
A Systematic Review: Challenges and Evaluations Related to Telemedicine as a Healthcare's Hope to Tackle COVID-19
}

\author{
Hikmahwati $^{1 *}$, Wahyu Sulistiadi ${ }^{2}$ \\ ${ }^{1}$ Policy and Health Law Magister Program, Faculty of Public Health Universitas Indonesia \\ ${ }^{2}$ Faculty of Public Health Universitas Indonesia \\ *Corresponding Author: Hikmahwati,:+62-87883771226
}

\begin{abstract}
The presence of COVID-19 pandemic makes Indonesian government established a health administration policy through telemedicine in the context of preventing the spread of COVID-19. Indonesia predicted has a high growth in telemedicine. However, previously Indonesia has never had any policy regulating telemedicine which involves direct interaction between doctors and patients. Meanwhile policies and legislation are expected as the determinants of telemedicine implementation. This study aims to analyze the challenges and evaluations for implementing telemedicine policy in health services in an effort to prevent the spread of COVID-19. The study design used was a systematic review that search for the challenges and evaluations made during the implementation of telemedicine policy. As a result, several things which become challenges in the implementation of telemedicine are the possibility of uncertainty that occurs in diagnosis by doctors, technological capabilities, data security and patient privacy, financing, law nor guidelines about telemedicine which is still minimal and challenges related to the individual patient's own problems. The telemedicine policy to prevent the spread of COVID-19 in Indonesia should not pave the way for health platforms or health service facilities to implement telemedicine without strict regulations. But the State must be present, serve and protect the people against the weaknesses of this practice.

Keywords: policy, determinants, guidelines, Internet of Things (IoT), implementation
\end{abstract}

\section{INTRODUCTION}

The number increasement of COVID-19 cases in the world has increased rapidly, WHO has also designated COVID-19 cases as a pandemic since March 11, 2020 [1] until now, pandemic COVID-19 has not ended yet. Instead of recognizing confirmed patients, ODP (people in monitoring) and PDP (pattients under surveillance), Indonesia also faced with OTG (people without symptoms) criterion [2]: This criterion arises based on the fact that the virus has a latent phase where even though it has no symptoms, the virus may one day be reactivated [3] when the person's immunity drops. Unfortunately, even in a latent phase, the virus still has the ability to move from one person to another. This is what causes the spread of the virus to become increasingly uncontrollable and invisible or undetectable. In order to reduce the impact or risk of being exposed to the virus in healthcare facilities, in April 2020 the Minister of Health issued Circular Number HK.02.01 / MENKES / 303/2020 which states that doctors can utilize information and communication technology in the form of telemedicine in providing healthcare services in the context of prevention of the spread of Corona Virus Disease (COVID-19) by paying attention to several aspects [4]. One of them are the delivery of healthcare services through telemedicine can be carried out during the Public Health Emergency and/or the Corona Virus Disease 2019 (COVID-19) National Disaster, in order to prevent the spread of Corona Virus Disease (COVID-19) and telemedicine services are carried out between doctors and patients, and/or between doctors and other doctors [4].

Indonesian Constitution Number 36 of 2009 about health explains that

"healthcare effort is any activity and/or series of activities carried out in an integrated, integrated and sustainable manner to maintain and improve the degree of public health in the form of disease prevention, health improvement, disease treatment, and health recovery by the government and/or the community"[5].

This healthcare effort is carried out by the government and local governments through the delivery of healthcare services, while the supervision of the implementation of healthcare services involves not only involving the government and local governments but also the community.

Today, we are faced with very fast technological advances. Now, we are also known Internet of Things 
(IoT) in medical healthcare. According to Swayamsiddha, et.al. (2020), Internet-of-Things (IoT) are a network of interconnected physical objects namely healthcare monitoring devices, home appliances, autonomous vehicles, sensors, smart meters, etc [6]. The foremost stakeholders of IoT today is telemedicine [7]. Telemedicine is known as the remote delivery of healthcare services, it could be consultations over teleconference or telecommunication and will finally allows healthcare professionals to evaluate, diagnose, and treat patients [8]. In more detail, the meaning of telemedicine are disclosed by the American Medical Association in Kaplan (2020), i.e.: 1) the realtime relationship between the doctor and the patient in two different locations, 2) the collection of images and stored data and forwarded for interpretation someday, 3) remote patient monitoring tools, which can be in the form of mobile medical devices (mHealth), wearable devices, and devices, and 4) virtual check-in through the patient's voice-only portal, messaging technology, and other like [9]. This telemedicine as new domain of ICT in a healthcare context provides two main benefits: as an emergency response to avoid the spread of pandemic COVID-19, mobility's limitations of patients and practitioners are needed, reduce the waiting time of medical tests and to conduct an independent health check [10]. According to the report from Mordor Intelligence, Indonesia have high growth in telemedicine progress (Figure 1) [8].

Indonesia itself has no statutory law which discuss about telemedicine with the scope of direct interaction between patients and doctors. Indonesia only has one regulation related to the implementation of telemedicine, that is the Minister of Health Regulation Number 20 of 2016 about Telemedicine Services between Healthcare Service Facilities, which means there is no direct interaction involving patients. Based on that, no party outside of doctors or other health workers is involved. Unlike the case with the core content in Circular Number HK.02.01/MENKES/303/2020 which regulates the Implementation of Healthcare
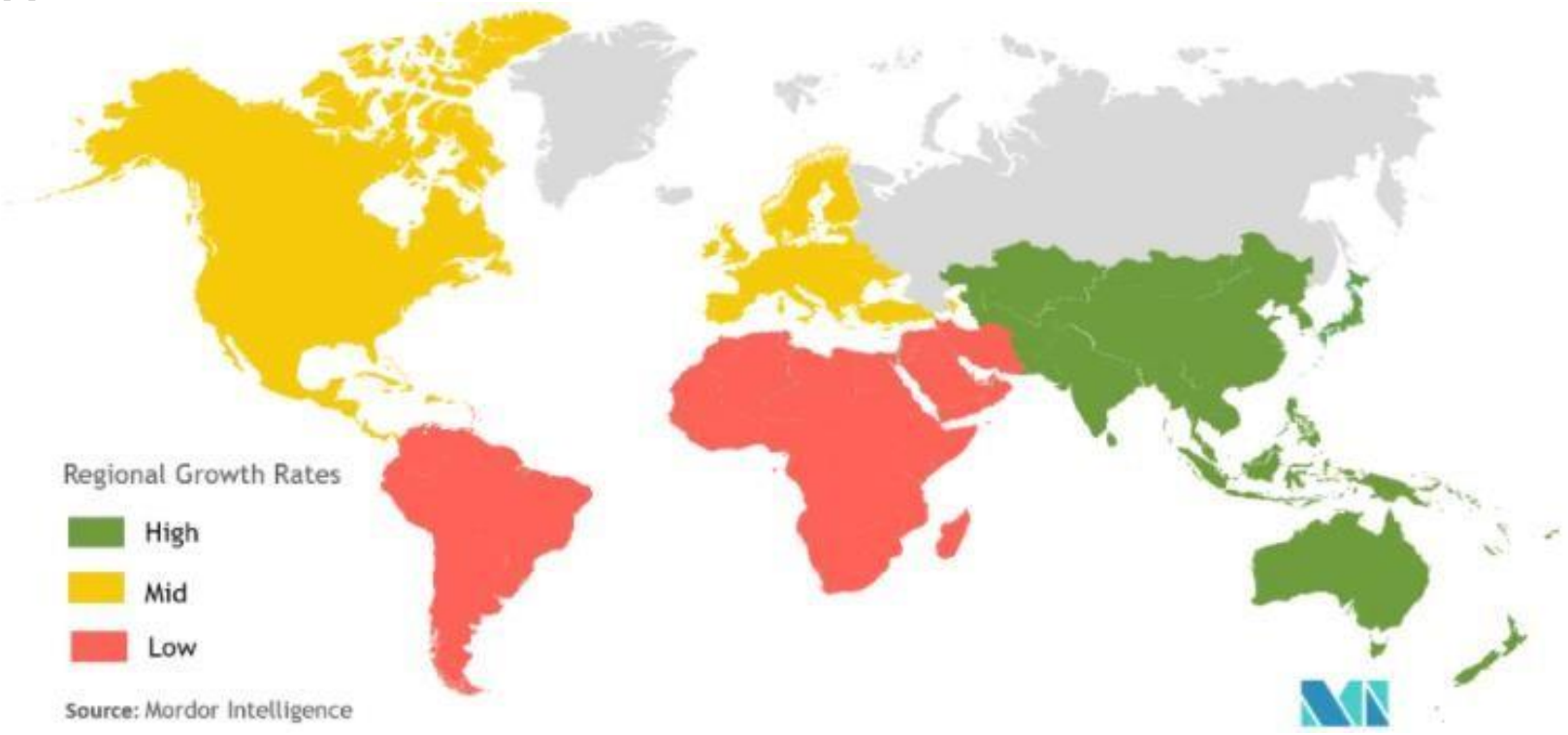

Figure 1. Telemedicine Market - Growth Rate by Region [8]

Services through the Use of Information and Communication Technology in the Context of Preventing the Spread of Corona Virus Disease (COVID-19) which involves a direct relationship between doctors and patients.

The use of technology and information in the world of healthcare has had many positive impacts, especially in Indonesia. In fact, with telemedicine, Indonesia is able to answer the challenge of social justice for all Indonesians by guaranteeing equal distribution of healthcare for all citizens. Especially in the era of the COVID-19 pandemic, it is known that telemedicine is indeed the main solution applied by healthcare systems around the world [11]. However, it turned out that the implementation of telemedicine itself found many challenges that must be faced. Like the results of a systematic review conducted by Al-Samarraie, et al. (2020) which states that technology, law, policy, finance, organizations, culture and the individual itself are challenges that Middle Eastern countries must resolve in implementing telemedicine practices [12].

Based on a survey conducted by WHO (2016) only $22 \%$ of countries reported having an explicit national telemedicine policy or strategy [13]. In fact, according to the survey, the relationship between the implementation of the telemedicine program with a certain legal framework and the country's population, the density of healthcare services, and patient access to the internet as well as communication technology is still unclear. Whereas the results of the literature review by Broen et al. (2007) found that policy and legislation are one of the determinants or determinants of telemedicine 
implementation besides technology, target group acceptance, financing, and organization [14].

The telemedicine policy that regulates the direct interaction between doctors and patients in Indonesia is in the form of a circular, so there is still a need to make a policy in the form of statutory laws. For this reason, it is important for Indonesia to immediately formulate a policy regulating telemedicine. In formulating a good policy, it must be based on evidence, whether it is research or evaluation of the results of policy implementation by other countries for the benefit of it and can be applied in Indonesia. Therefore, this paper aims to analyze the challenges and evaluate the implementation of telemedicine policies in healthcare services in an effort to prevent the spread of COVID-19.

\section{METHOD}

This paper is a systematic review with the guidelines Preferred Reporting Items for Systematic Reviews and Meta-Analyzes (PRISMA). In screening steps, inclusion criteria were determined by the PICOS method which consisted of population, intervention, comparison, outcomes and study type. The study population can be a patient, a population of a certain age, to certain characteristics depending on the interests of the authors [15]. The population concern in this paper is health services during the COVID-19 pandemic. The intervention that is wanted to be seen in this study is the use of information and communication technology in the health sector or simply referred to as telemedicine. The outcomes to be seen are the challenges, obstacles, problems, disturbances and evaluations in the implementation of telemedicine policies.

The literature search was performed using the ScienceDirect and Sage Journals databases. The literature used is in the form of full-text reviews and research articles. The search is limited to literature from 2019 to the time of the COVID-19 pandemic (2020). The keywords used in the literature search were telemedicine AND COVID-19 AND healthcare AND (challenges OR barriers OR determinants) AND implementation AND policy AND Evaluation. At the literature identification stage, 122 literatures was found in the Science Direct database and 30 literatures on the Sage Journals database (Figure 2). Then after duplication screening, there was no literature needed to be excluded so that the literature found in both databases was 152 literatures. Screening steps carried out by observing titles and abstracts from all selected literature and total of 96 literatures had to be excluded because they were not in line with the aims of the paper. Then, as many as 26 literatures were obtained and were screened full text. After that, we obtained as many as 21 literature excluded so that there were 5 literature that were used as reference to answer the objectives of this literature review.

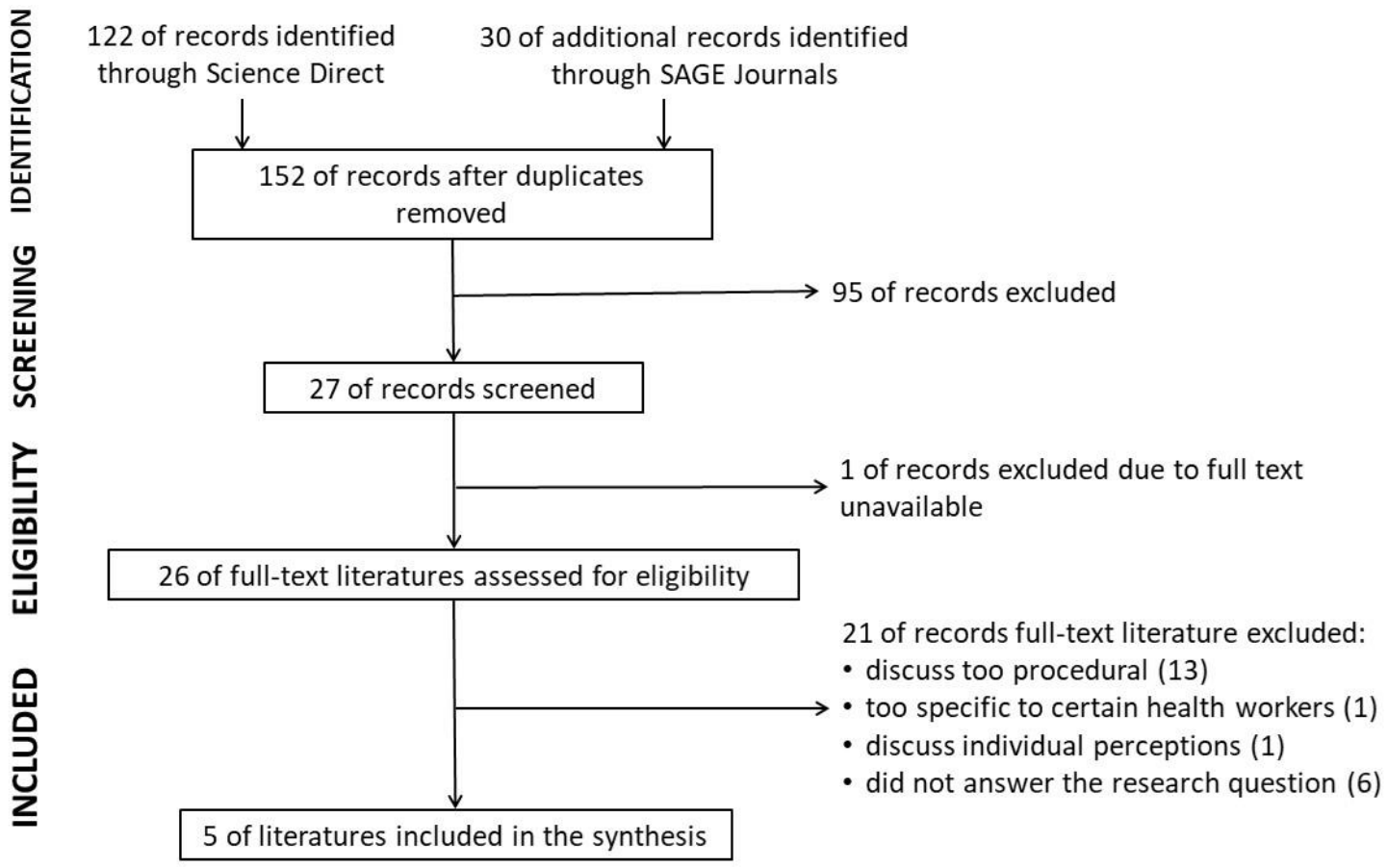

Figure 2. PRISMA Flow Chart 


\section{RESULTS}

Table 1. Summary Results of Systematic Review

\begin{tabular}{|c|c|c|c|}
\hline Study & Study Type & Interventions & Outcomes \\
\hline $\begin{array}{l}\text { Expansion of } \\
\text { Telehealth } \\
\text { Across the Rural- } \\
\text { Urban } \\
\text { Continuum [16] }\end{array}$ & $\begin{array}{l}\text { review } \\
\text { article }\end{array}$ & $\begin{array}{l}\text { Telemedicine to } \\
\text { rural-urban } \\
\text { communities }\end{array}$ & $\begin{array}{l}\text { Challenges that occurred during the implementation of } \\
\text { telemedicine: } \\
\text { 1. Funding for health service providers to purchase } \\
\text { equipment and equipment for conducting } \\
\text { telemedicine } \\
\text { 2. Permitted expenses, such as internet access to monitor } \\
\text { patients remotely } \\
\text { 3. Expanding the recipient of contacts and services, with } \\
\text { reimbursement mechanisms or replacement payments } \\
\text { 4. The issue of privacy, based on the policies applicable } \\
\text { in the region, the government returns the obligation to } \\
\text { maintain privacy to each health worker } \\
\text { Evaluations: } \\
\text { 1. Telemedicine is still an option when face-to-face } \\
\text { consultations are not possible } \\
\text { 2. Health insurance must pay for doctor visits to homes } \\
\text { if telemedicine cannot be done. Likewise, consulting } \\
\text { financing only through telemedicine must also be } \\
\text { covered by health insurance. } \\
\text { There should be a permanent policy that allows all } \\
\text { health care providers to fully practice their licensing } \\
\text { and training. }\end{array}$ \\
\hline $\begin{array}{l}\text { Telemedicine, } \\
\text { COVID-19, and } \\
\text { disparities: Policy } \\
\text { implications [11] }\end{array}$ & $\begin{array}{l}\text { review } \\
\text { article }\end{array}$ & $\begin{array}{l}\text { implementation of } \\
\text { telemedicine }\end{array}$ & $\begin{array}{l}\text { Challenges that occurred during the implementation of } \\
\text { telemedicine: } \\
\text { 1. Heterogenicity of the population, both in terms of } \\
\text { inability to access internet to economic capacity } \\
\text { which causes them not to have internet access } \\
\text { 2. Patient data safety lapses } \\
\text { Evaluations: } \\
\text { 1. Extend the reimbursement system } \\
\text { 2. There should be a permanent policy advising all } \\
\text { health care providers to implement telemedicine in } \\
\text { the appropriate case } \\
\text { 3. Policies that maintain the security of patient data in } \\
\text { detail } \\
\text { 4. Inviting the participation of healthcare service } \\
\text { facilities in contributing to providing equitable } \\
\text { telemedicine services to all citizens }\end{array}$ \\
\hline $\begin{array}{l}\text { COVID-19: } \\
\text { Unmasking } \\
\text { Telemedicine [17] }\end{array}$ & $\begin{array}{l}\text { review } \\
\text { article }\end{array}$ & $\begin{array}{l}\text { implementation of } \\
\text { telemedicine }\end{array}$ & $\begin{array}{l}\text { Challenges that occurred during the implementation of } \\
\text { telemedicine: } \\
\text { 1. Establish limits on which patients can be } \\
\text { telemedicine and which ones need to be visited } \\
\text { 2. If telemedicine is carried out, it is necessary to } \\
\text { determine what kind of telemedicine (synchronous } \\
\text { or asynchronous) } \\
\text { 3. Access a reliable internet connection } \\
\text { 4. Privacy security to protect patient's personal health } \\
\text { information. } \\
\text { Evaluations: } \\
\text { 1. Adequate training for service providers } \\
\text { 2. Handbook or instruction manual for patients }\end{array}$ \\
\hline
\end{tabular}




\begin{tabular}{|c|c|c|c|}
\hline & & & $\begin{array}{l}\text { 3. Payment will be refunded by health insurance } \\
\text { 4. Involving all related parties } \\
\text { 5. Prepare doctors for telemedicine } \\
\text { 6. There is a special agency that maintains the security } \\
\text { and confidentiality of patient data } \\
\text { 7. The need for encryption for any transmission over } \\
\text { video or internet protocols as well as encryption on } \\
\text { private networks } \\
\text { 8. All vendors serving the telemedicine platform must } \\
\text { be registered and follow the protocol established by } \\
\text { a special agency that maintains the security and } \\
\text { confidentiality of patient data }\end{array}$ \\
\hline $\begin{array}{l}\text { Rapid Deployment } \\
\text { of Chiropractic } \\
\text { Telehealth } \\
\text { at } 2 \text { Worksite } \\
\text { Health Centers in } \\
\text { Response to } \\
\text { the COVID-19 } \\
\text { Pandemic: } \\
\text { Observations from } \\
\text { the Field [18] }\end{array}$ & $\begin{array}{l}\text { research } \\
\text { article }\end{array}$ & $\begin{array}{l}\text { implementation of } \\
\text { telemedicine }\end{array}$ & $\begin{array}{l}\text { Challenges that occurred during the implementation of } \\
\text { telemedicine: } \\
\text { 1. Privacy laws and their use of video communications } \\
\text { 2. Possibility of malpractice } \\
\text { 3. Reimbursement } \\
\text { 4. Service terminology and coding is confusing } \\
\text { 5. Learning facilities for providers and staff when } \\
\text { implementing telemedicine } \\
\text { 6. It is difficult to make a diagnosis via video } \\
\text { 7. It may be difficult to triage patients with potential } \\
\text { Evaluations: } \\
\text { 1. Preparation of telemedicine implementation } \\
\text { guidelines } \\
\text { 2. Ensure that telemedicine has been protected by their } \\
\text { respective professional organizations } \\
\text { Conduct research on the validity of virtual general } \\
\text { physical examination, because research on this }\end{array}$ \\
\hline $\begin{array}{l}\text { Regulatory, Legal, } \\
\text { and } \\
\text { Ethical } \\
\text { Considerations of } \\
\text { Telemedicine [19] }\end{array}$ & $\begin{array}{l}\text { review } \\
\text { article }\end{array}$ & $\begin{array}{l}\text { implementation of } \\
\text { telemedicine }\end{array}$ & $\begin{array}{l}\text { Things that need to be considered in terms of legal } \\
\text { aspects that can be done in filling out the informed } \\
\text { consent, are: } \\
\text { 1. Documentation of the patient, provider, and } \\
\text { credentials } \\
\text { 2. Type of telemedicine used (synchronous, } \\
\text { asynchronous, etc.) } \\
\text { 3. A statement from the health professional that he can } \\
\text { manage the patient's condition through telemedicine } \\
\text { 4. Security measures taken to protect patient health data } \\
\text { and address potential privacy risks } \\
\text { 5. A clause describing the possibility of the service } \\
\text { provider losing patient information due to a technical } \\
\text { failure } \\
\text { 6. Statement of patient consent to forward health } \\
\text { information to third parties }\end{array}$ \\
\hline
\end{tabular}

\section{DISCUSSION}

The summary results of the literature search are presented in Table 1. Overall, the challenges and evaluation occur during the telemedicine process revolve around the possibility of uncertainty by doctors that occurs in diagnosis step, technology capability, data security and patient privacy, financing, law nor 
guidelines regarding the implementation of telemedicine which still minimal and challenges related to the patient's individual problems. In addressing the possibility of uncertainty in the diagnosis by doctors, the results of several reviews indicate that training for health workers is needed. The training can be technical problem such as operating software, interpreting the results of medical equipment to mini-arrangements that have an impact on diagnosis, such as the ability to communicate to patients in adjusting the location or position of the lights so that the information captured by the camera screen can be seen clearly on the doctor's screen. This training is important where in fact via face-to-face processions there is still the possibility of medical errors. Based on research conducted by Sulistiadi, et al (2020), medical errors can occur due to medication errors, wrong treatment processes, and wrong drug routes [20]. Therefore, in line with this study, recommendations are conveyed through the research of Hare, et al. (2020) that in addition to training for healthcare workers, guidelines for conducting telemedicine must also be conveyed properly to patients [17]. Medical errors that occur due to wrong drug routes can be caused by conveying wrong information to patients or information that is not conveyed to patients. Therefore, it is important to make a guideline or set of meanings for the terms used in the electronic prescribing used in telemedicine. The similarity in the delivery of this information must also be ensured not only by doctors, but also by pharmacists who are responsible for delivering drugs to patients. If the telemedicine platform has used an official pharmacy as a drug provider, then the pharmacy practice has been guaranteed by law. However, things were different when the telemedicine platform did not cooperate with official pharmacies.

Patient safety is at stake. For this reason, both Ortega and Hare (2020) reveal the importance of the existence of policies that maintain the security of patient data in detail, even according to Hare, et al. it is necessary to have a special agency that ensures the safety of patient data. According to the author's opinion, in a health or telemedicine context, it is better for the agency to stand alone and regulate all matters related to telemedicine, including the use of connections, data networks and so on. So, we can avoid if someday data theft happened in one institution, it would not be an impact on other institutions performance. Furthermore, Fields et al. (2020) actually provide a solution to the problem of patient data security by providing informed consent that documents the patient, provider, and credentials, the type of telemedicine used (synchronous, asynchronous, etc.), statements of health professionals concerned with the patient. that the health worker is able to manage the patient's condition through telemedicine, security measures taken by the administrator to protect patient health data and an explanation of potential privacy risks, a clause explaining the possibility of a service provider losing patient information caused by technical failure and a statement of patient consent to forward the information health to third parties [19]. Through this informed consent, there have actually been agreements built between patients, doctor and also the telemedicine organizer so as to minimize claims that may arise in the future.

Technological capabilities can be closely related to the support of certain governments in the development of healthcare service mechanisms through telemedicine. This can be seen in terms of the allocation of government funds to healthcare service facilities to purchase equipment and devices for telemedicine. Not only that, the allowable amount of expenditure, such as internet access to monitor patients remotely, is also one of the government's support so that healthcare service facilities could work together in order to implement telemedicine as an alternative treatment mechanism if face-to-face treatment is not possible. Free internet access for users will certainly affect the implementation of telemedicine outside of the reimbursement mechanism which, according to all the results of this literature search, will have an impact on the favor of this mechanism in the public. In fact, Ortega et al (2020) stated that there should be a permanent policy advising all health service providers to carry out telemedicine if these conditions are possible.

\section{CONCLUSION}

Apart from the advantages of implementing telemedicine, there were various challenges and evaluations during the implementation process. However, referring to the COVID-19 condition where face-to-face contact between doctors and patients needs to be avoided, telemedicine is the only way out. The various challenges that need to be prepared by the State in order to prevent the spread of COVID-19 must be done, including everything related to telemedicine. It should not only open roads and spaces for healthcare platforms and healthcare service facilities to implement telemedicine. Instead, the State must be present, serve and protect the people from this practice. This can be started with the formulation of a permanent policy that regulates the implementation of telemedicine services, protocols that must be implemented by healthcare service facilities, healthcare platforms, healthcare workers and the community as patients. Not only that, some training for healthcare workers are also needed in the implementation of this service.

\section{RECOMMENDATIONS}

Based on the results of the systematic review observed in the implementation of the telemedicine policy, some notes are captured by author as a recommendation to Indonesian government in determining telemedicine policies in the future is that the government should immediately establish an agency/institution that is specifically responsible for maintaining data security and patient privacy related to 
provision of healthcare services through telemedicine. In addition, the government needs to immediately formulate policies that regulate telemedicine specificly, the technical implementation of telemedicine, and the government's monitoring and control mechanisms for the implementation of telemedicine through a statutory regulation. Finally, the government needs to allocate funds and support technology and communication facilities as well as training for health service providers and health workers, especially health service providers who are under the government's responsibility to implement telemedicine.

\section{REFERENCES}

[1] WHO, "WHO Director-General's opening remarks at the media briefing on COVID-19 11 March 2020," 2020. https://www.who.int/dg/speeches/detail/whodirector-general-s-opening-remarks-at-themedia-briefing-on-covid-19---11-march-2020 (diakses Apr 13, 2020).

[2] Gugus Tugas Percepatan Penanganan Covid19, "Pedoman Penanganan Cepat Medis dan Kesehatan Masyarakat Covid-19 di Indonesia," 23 Maret, hal. 1-38, 2020. file://C:/Users/asus/Downloads/Pedoman_Pe nanganan_Cepat_Medis_dan_Kesehatan_Ma syarakat_COVID-

19_di_Indonesia.pdf\%20(2).pdf

[3] C. M. Traylen et al., "Virus reactivation: A panoramic view in human infections," Future Virol., vol. 6, no. 4, hal. 451-463, 2011, https://doi.org/10.2217/fvl.11.21

[4] Kementerian Kesehatan, "Surat Edaran Nomor HK 02.01/MENKES/303/2020 Penyelenggaraan Pelayanan Kesehatan melalui Pemanfaatan Teknologi Informasi dan Komunikasi dalam Rangka Pencegahan Penyebaran CORONA VIRUS DISEASE (COVID-19)," 2020. https://covid19.hukumonline.com/wpcontent/uploads/2020/07/surat_edaran_mente ri_kesehatan_nomor_hk_02_01_menkes_303 _2020_tahun_2020.pdf

[5] Kementerian Hukum dan HAM, "Undang Undang Nomor 36 Tahun 2009 tentang Kesehatan," 2009. https://jdih.kemenkeu.go.id/fulltext/2009/36t ahun2009uu.htm

[6] S. Swayamsiddha dan C. Mohanty, "Application of cognitive Internet of Medical
Things for COVID-19 pandemic," Diabetes Metab. Syndr. Clin. Res. Rev., vol. 14, no. 5, hal. 911-915, 2020, https://doi.org/10.1016/j.dsx.2020.06.014

[7] B. Farahani, F. Firouzi, V. Chang, M. Badaroglu, N. Constabt, dan K. Mankodiya, "Towards fog-driven IoT eHealth: Promises and challenges of IoT in medicine and Healthcare," Futur. Gener. Comput. Syst. FGCS, vol. 78, no. 2, 2018, https://doi.org/10.1016/j.future.2017.04.036

Mordor Intelligence, "Telemedicine Market Growth, Trends, and Forecast (2020 - 2025)," 2020.

https://www.mordorintelligence.com/industry -reports/global-telemedicine-market-industry (diakses Sep 18, 2020).

B. Kaplan, "REVISTING HEALTH INFORMATION TECHNOLOGY ETHICAL, LEGAL, and SOCIAL ISSUES and EVALUATION: TELEHEALTH/TELEMEDICINE and COVID-19," Int. J. Med. Inform., hal. 104239, 2020, https://doi.org/10.1016/j.ijmedinf.2020.10423 9

[10] P. Baudier, G. Kondrateva, dan C. Ammi, "The future of Telemedicine Cabin? The case of the French students' acceptability," Futures, vol. 122, hal. 102595, Sep 2020, https://doi.org/10.1016/j.futures.2020.102595

[11] G. Ortega et al., "Telemedicine, COVID-19, and disparities: Policy implications," Heal. Policy Technol., Agu 2020, https://doi.org/10.1016/j.hlpt.2020.08.001

[12] H. Al-Samarraie, S. Ghazal, A. I. Alzahrani, dan L. Moody, "Telemedicine in Middle Eastern countries: Progress, barriers, and policy recommendations," Int. J. Med. Inform., vol. 141, no. March, hal. 104232, 2020 , https://doi.org/10.1016/j.ijmedinf.2020.10423 2

[13] WHO, Report of the third global survey on eHealth Global Observatory for eHealth Global diffusion of eHealth: Making universal health coverage achievable. 2016. https://www.who.int/goe/publications/global_ diffusion/en/. 
[14] T. H. F. Broens, R. M. H. A. Huis in't Veld, M. M. R. Vollenbroek-Hutten, H. J. Hermens, A. T. van Halteren, dan L. J. M. Nieuwenhuis, "Determinants of successful telemedicine implementations: A literature study," $J$. Telemed. Telecare, vol. 13, no. 6, hal. 303309, Sep 2007, https://doi.org/10.1258/13576330778164495 1

[15] A. Liberati et al., The PRISMA statement for reporting systematic reviews and metaanalyses of studies that evaluate health care interventions: explanation and elaboration, vol. 62, no. 10.2009. https://doi.org/10.1016/j.jclinepi.2009.06.006

[16] A. D. Bagchi, "Expansion of Telehealth Across the Rural-Urban Continuum," State Local Gov. Rev., vol. 51, no. 4, hal. 250-258, 2019, https://doi.org/10.1177/0160323X20929053

[17] N. Hare et al., "COVID-19: Unmasking Telemedicine," J. Allergy Clin. Immunol. Pract., vol. 8, no. 8, hal. 2461-2473.e3, 2020, https://doi.org/10.1016/j.jaip.2020.06.038

[18] B. N. Green, T. V. Pence, L. Kwan, dan J. Rokicki-Parashar, "Rapid Deployment of Chiropractic Telehealth at 2 Worksite Health Centers in Response to the COVID-19 Pandemic: Observations from the Field," $J$. Manipulative Physiol. Ther., 2020, https://doi.org/10.1016/j.jmpt.2020.05.008

[19] B. G. Fields, "Regulatory, Legal, and Ethical Considerations of Telemedicine," Sleep Med. Clin., vol. 15, no. 3, hal. 409-416, 2020, https://doi.org/10.1016/j.jsmc.2020.06.004

[20] W. Sulistiadi, A. G. Purwadi, dan A. Asyary, "Addressing the Medical Errors in the ReOrganized Healthcare in Indonesia," Ann. Ig., vol. 32, no. 5, hal. 567-576, 2020, https://doi.org/10.7416/ai.2020.2376 